\title{
Effect of septal deviation on osteomeatal complex distances
}

\section{Septum \\ deviasyonunun mesafeleri üzerine etkisi \\ osteomeatal}

kompleks

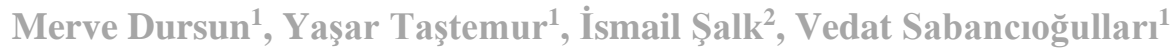

'Department of Anatomy, Sivas Cumhuriyet University Faculty of Medicine, Sivas, Turkey

${ }^{2}$ Department of Radiology, Sİvas Cumhuriyet University Faculty of Medicine, Sivas, Turkey

Corresponding author: Merve Dursun, MD, Department of Anatomy, Sivas Cumhuriyet University Faculty of Medicine, Sivas, Turkey

E-mail: mrvylmz3894@gmail.com

Received/Accepted: October 08, 2021 /December 24, 2021

Conflict of interest: There is not a conflict of interest.

\section{SUMMARY}

Objective: It is known that deviation of the septum plays an etiological role in the obstructions formed in the osteomeatal complex. In this study, it was aimed to evaluate the effect of the degree of deviation of the nasal septum on the distances between the bone structures forming the osteomeatal complex.

Method: The research universe was obtained by retrospectively scanning 1200 computed tomography (CT) images of January 2018-December 2019 in the PACS archive of the Department of Radiology of Sivas Cumhuriyet Faculty of Medicine Hospital. A total of 453 individuals, 228 females and 225 males (18-82 years old) meeting the criteria for inclusion in the study were included. Septal deviation angle was measured. Individuals were grouped according to the degree of septal deviation. Osteomeatal complex spaces $(\mathrm{OMC})$ were evaluated according to the degree of septal deviation. In the study, the distance between OMC spaces was also investigated in the presence of sinusitis.

Results: In the septum, the distance between lamina papyricea and middle nasal concha (LP-MNC) at medium and high grades was found to be large in the opposite direction of the deviation. The distance between the lamina papyricea and uncinate process [ethmoidal infundibulum (LP-UP)] was small on the right side in low-grade deviation to the right. When the distance between uncinate process and middle nasal concha (UP-MNC) and the distance between LP-UP was compared, it was found to be smaller in the direction of deviation in individuals with middle deviation to the left ( $\mathrm{p}<$ 0.05 ). While the right osteometal complex spaces were found to be smaller than the control group, the distance between UP-MNC from the left osteomeatal spaces made a difference with the control group.

Conclusions: Degrees and type of septal deviation were effective in narrowing the osteomeatal complex spaces. It was determined that OMC distances did not change with the presence of sinusitis. It is thought that it may be useful to evaluate the degree of septal deviation in obstruction of osteomeatal complex spaces and mucosal changes in the paranasal region.

Keywords: Nasal septum, deviation, osteomeatal, sinusitis.
ORCID IDs of the authors: M.D. 0000-0002-1947-7218 Y.T. 0000-0002-2016-0592 İ.Ş. 0000-0002-5156-6923 V.S. 0000-0001-9059-6554 
Amaç: Septum deviasyonunun osteomeatal komplekste oluşan tıkanıklarda etyolojik olarak rol oynadığı bilinmektedir. $\mathrm{Bu}$ çalışmada septum nasi deviasyon derecesinin, osteomeatal kompleksi oluşturan kemik yapılar arasındaki mesafeler üzerine etkisi değerlendirildi.

Yöntem: Araştırma, paranasal bilgisayarlı tomografi görüntüleri üzerinde yapılan retrospektif bir çalışmadır. Araştırma evreni; Sivas Cumhuriyet Üniversitesi Tıp Fakültesi Hastanesi Radyoloji Anabilim Dalının PACS arşivinde bulunan Ocak 2018-Aralık 2019 tarih aralığına ait 1200 bilgisayarlı tomografi (BT) görüntüsünün taranması ile elde edildi. Araştırmaya alınabilme kriterlerini taşıyan 228 kadın ve 225 erkek (18-82 yaş) toplamda 453 birey çalışmaya dahil edildi. Septum deviasyon açısı ölçüldü. Bireyler septum deviasyonu derecesine göre gruplandırıldı. Osteomeatal kompleks boşlukları septum deviasyon derecesine göre değerlendirildi. Çalışmada aynı zamanda sinüzit varlığınında osteomeatal kompleks boşlukları (OMC) boşlukları arası mesafe araştırıldı.

Bulgular: Septumda orta ve yüksek derecelerde lamina paprisea-concha nasalis medius (LP-MNC) arası mesafe deviasyon yönünün tersinde büyük olarak tespit edildi. Lamina paprisea- proc.uncinatus [infundibulum ethmoidale (LPUP)] arası mesafe sağa düşük dereceli deviasyonda deviasyon yönünde küçüktü. Processus uncinatus-concha nasalis medius (UP-MNC) ile LP-UP arası mesafe karşılaştırıldığında sola orta deviasyonu olan bireylerde deviasyon yönünde daha küçük tespit edildi $(\mathrm{p}<0.05)$. Sağ osteometal kompleks boşlukları kontrol grubuna göre küçük tespit edilirken, sol taraf osteomeatal boşluklarından UP-MNC arası mesafe kontrol grubu ile fark oluşturdu.

Sonuç: Septum deviasyonu orta ve yüksek dereceleri osteomeatal kompleks boşluklarında oluşan daralmalarda etkili oldu. Osteomeatal kompleks boşluklarının mesafelerinin sinüzit varlığı ile değişim göstermediği tespit edildi. Osteomeatal kompleks boşluklarının obstrüksiyonu ve paranasal bölge mukozal değişikliklerinde septum deviasyon derecesinin değerlendirilmesi faydalı olabileceği düşünülmektedir.

Anahtar sözcükler: Nasal septum, deviasyon, osteomeatal, sinüzit

\section{INTRODUCTION}

The anatomy of the paranasal region is quite complex and there are great differences between individuals ${ }^{1}$. In particular, variations in the osteomeatal complex may play a role in the pathogenesis of inflammatory diseases of the paranasal sinuses ${ }^{2}$. It has been suggested that deviation of the nasal septum, concha bullosa, paradoxical middle concha, pneumatization of the uncinate process, giant ethmoidal bulla, haller cell and excessively pneumatized agger nasi cell may cause stenosis in the osteomeatal complex ${ }^{2}$.

The osteomeatal complex, consisting of the ethmoidal infundibulum, uncinate process, hiatus semilunaris, frontal recess, anterior ethmoidal cells, and maxillary sinus ostium, functions as a common drainage pathway for the frontal, maxillary, and anterior ethmoidal sinuses ${ }^{3}$. Nasal septal deviation may also affect the distance between the lamina papyricea middle nasal concha and the ethmoidal infundibulum ${ }^{4}$.

In this study, we aimed to investigate the effect of the degree of deviation of the nasal septum on the distances between the bone structures forming the osteomeatal complex and its relationship with the mucosal changes of the paranasal sinuses, using paranasal CT images.

\section{MATERIAL AND METHODS}

The study is a retrospective study using paranasal CT image recordings. A total of 453 individuals, 228 women and 225 men, between the age of minimum 18 and maximum 82 years, were included in the study from 1200 tomographies of January 2018-December 2019, in the PACS archive of the Radiology Department at Sivas Cumhuriyet University.

Individuals with previous sinonasal surgery anatomical damage, congenital anomaly, nasal polyposis, sinonasal tumor or inappropriate tomography, under 18 years of age and without clear osteomeatal complex were not included in the study. Individuals were divided into groups in terms of nasal septal deviation and presence of sinusitis and osteomeatal complex spaces were compared to the right and left.

CT scans were obtained using 64-slice multidetector CT scanner (Aquilion CX, Toshiba Medical Systems, Japan). 120kV, 150mAs during CT examination; $64 \times 0.5$ detector collimation, 5 $\mathrm{mm}$ coronal section thickness was used.

Septal deviation angle in coronal section; It was measured by drawing a straight line between the crista galli and the nasal crest of the maxilla. While septums on the line were considered normal, a second line was drawn from the crista galli to the point where the curvature was highest in those not on the line but with deviation (Fig.1). The angle of deviation was determined by the angle between the two lines ${ }^{5}$. The direction of nasal septal deviation was determined as the convexity side of the septal curvature. According to the size of the nasal septal deviation angle, they were divided into three groups as low $\left(<9^{\circ}\right)$, medium $\left(9^{\circ}-15^{\circ}\right)$, high $(>$ $\left.15^{\circ}\right)^{6,7}$. 


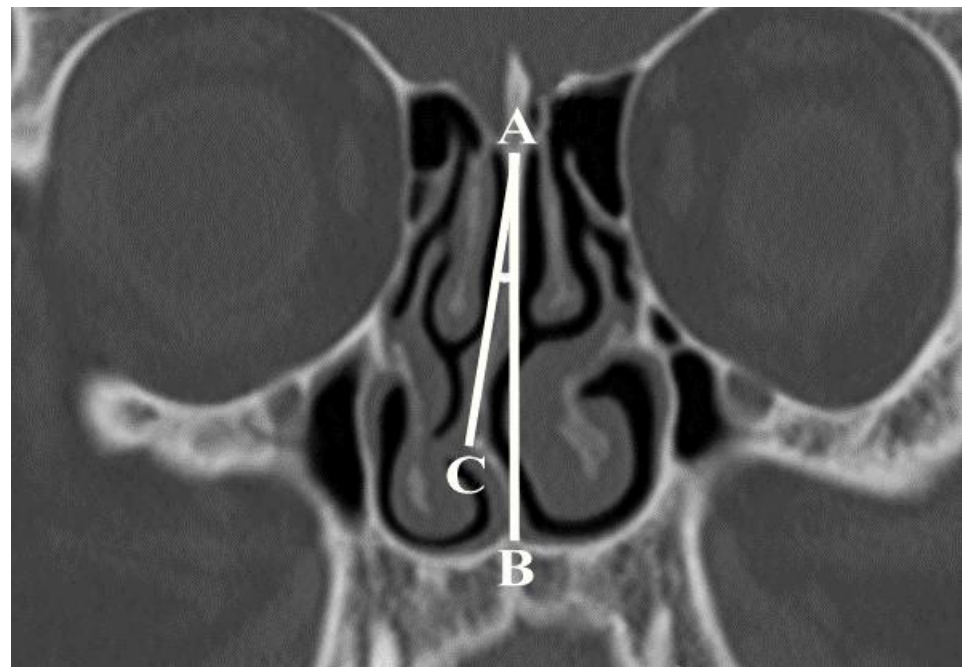

Figure 1: Method of measurement of septal angle on CT scan A: Crista galli, B: Nasal crest of the maxilla C: The point where the septal deviation is most

Images were adjusted to the level at which bone structures could be clearly distinguished. The first measurement was measured bilaterally by taking the narrowest bone distance measurement between LP-UP (infundibulum width), LP-MNC, UP-MNC (Fig. 2).

In cases where there was anatomical variation (haller cell or ethmoidal bulla) in the ethmoidal infundibulum, the medial wall of these structures was accepted as the border instead of the lamina papyricea for infundibulum width and LP-MNC measurements. In cases where the bone structure could not be clearly observed due to the uncinate process being very thin, the midpoint of the uncinate process thickness was determined as the bone border. The width of the spaces completely closed by the mucosa was assumed to be zero ${ }^{3}$.

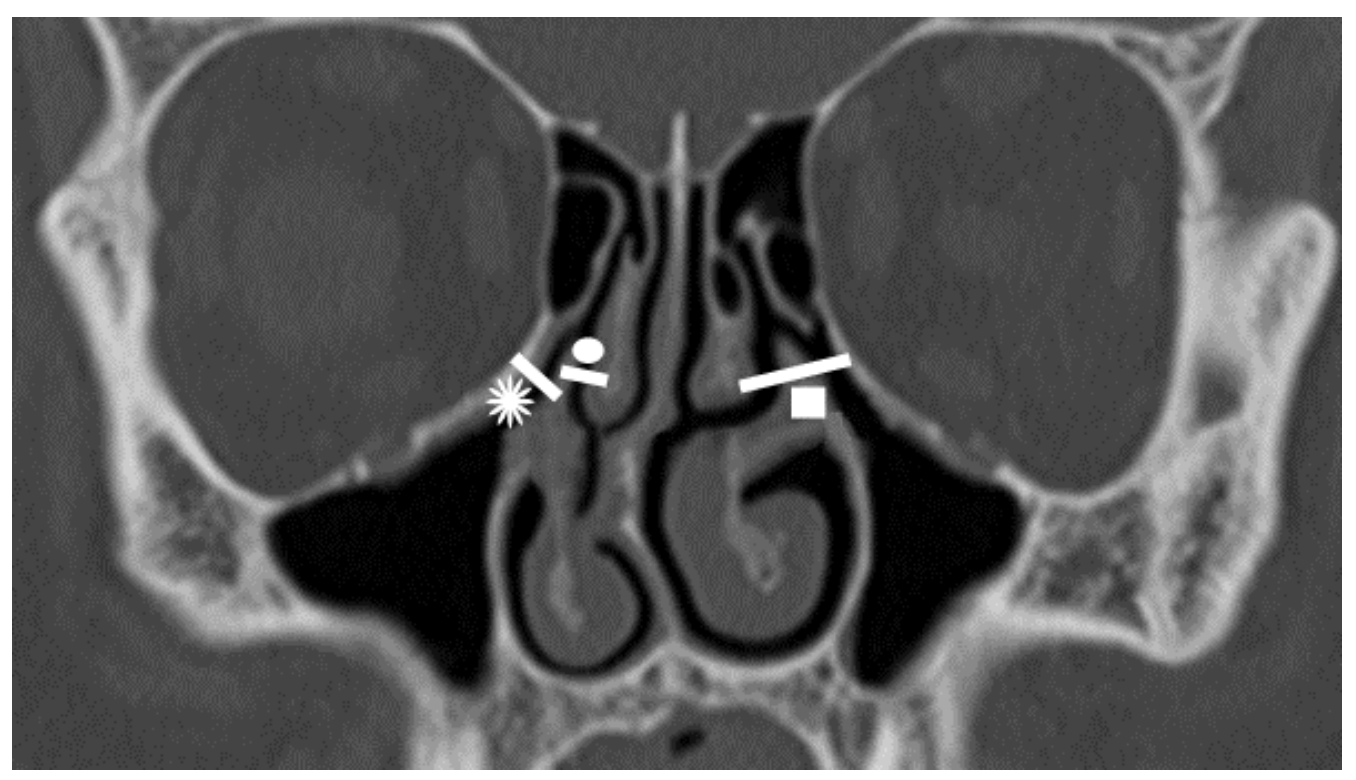

Fig. 2. $\square$ Lamina papyricea-Middle nasal concha (LP-MNC) Lamina papyricea -Uncinate process (LP-UP) Uncinate process- Middle nasal concha (UP-MNC) 
Mc Gay Lund classification was used to evaluate mucosal changes. In this classification, normal sinus was scored as 0 , minor mucosal thickening 1 , major mucosal thickening 2, total opacity or fluid level 3. In the cases participating in the study, those who scored 1 point or more were considered as sinusitis ${ }^{8}$.

The data were analyzed in SPSS 22.0. The Kolmogorov-Smirnov test, the Paired Samples t test, independent sample $\mathrm{t}$ test were used to measure the data. P-value less than 0.05 were statistically significant. The data was expressed in arithmetic mean (X), standard deviation (SD), number (n) in the tables.

\section{RESULTS}

When the distance between the right LP-MNC and the distance between the left LP-MNC were compared, no difference was observed in the control and S-shaped deviations (Table 1). It was observed that the LP-MNC distance was longer on the left side in individuals with low, medium and high grade deviations of the septum to the right. When the distance between the right LP-UP was compared with the distance between the left LP-
UP, it was determined that the distance between LP-UP on the left side was greater in individuals with low grade deviations of the septum to the right (Table 2). It was determined that the distance LPMNC was greater on the right side in individuals with medium and high grade deviation to the left in the septum $(\mathrm{p}<0.05)$. When the distance between right UP-MNC and left UP-MNC was compared, it was determined that the distance between UPMNC was greater on the right side in individuals with medium grade deviation to the left $(\mathrm{p}<0.05)$. When the distance between the right LP-UP was compared with the distance between the left LP$\mathrm{UP}$, it was determined that the distance between LP-UP on the right side was greater in individuals with medium grade deviation to the left $(\mathrm{p}<0.05)$ (Table 3).

When the widths of OMC spaces/distances (rightleft) are compared with the presence of sinusitis, the distance between right-left LP-MNC in individuals without maxillary sinusitis was found to be large on the left side. In individuals without sphenoid sinusitis, the right LP-UP and left LP-UP distances were found to be greater on the right side $(\mathrm{p}<0.005)$.

Table 1: Comparison of OMC spaces/distances according to septal deviation type (right-left)

\begin{tabular}{|c|c|c|c|c|c|c|c|c|c|}
\hline & \multicolumn{2}{|c|}{ LP-MNC } & \multirow[t]{2}{*}{$\mathbf{p}$} & \multicolumn{2}{|c|}{ UP-MNC } & \multirow[t]{2}{*}{$\mathbf{p}$} & \multicolumn{2}{|c|}{ LP-UP } & \multirow[t]{2}{*}{$\mathbf{p}$} \\
\hline & Right & Left & & right & left & & Right & left & \\
\hline $\begin{array}{l}\text { Control } \\
\text { Group } \\
\mathbf{n}=\mathbf{8 1}\end{array}$ & $5.5 \pm 2.1$ & $5.8 \pm 1.9$ & 0.061 & $1.9 \pm 1.2$ & $1.8 \pm 1.0$ & 0.759 & $2.7 \pm 1.5$ & $2.7 \pm 1.4$ & 0.904 \\
\hline $\begin{array}{l}\text { S-Shaped } \\
\text { Deviation } \\
\mathbf{n}=\mathbf{1 0 0}\end{array}$ & $5.8 \pm 2.0$ & $12.5 \pm 6.4$ & 0.310 & $2.0 \pm 1.0$ & $1.9 \pm 1.0$ & 0.128 & $2.9 \pm 1.3$ & $3.2 \pm 1.7$ & 0.082 \\
\hline
\end{tabular}

Table 2: Comparison of OMC spaces/distances according to right septum deviation degree (right-left)

\begin{tabular}{|c|c|c|c|c|c|c|c|c|c|}
\hline \multirow{2}{*}{$\begin{array}{l}\text { Right } \\
\text { septal } \\
\text { deviation } \\
\text { degree }\end{array}$} & \multicolumn{2}{|c|}{ LP-MNC } & \multirow[t]{2}{*}{$\mathbf{P}$} & \multicolumn{2}{|c|}{ UP-MNC } & \multirow[t]{2}{*}{$\mathbf{p}$} & \multicolumn{2}{|c|}{ LP-UP } & \multirow[t]{2}{*}{$\mathbf{p}$} \\
\hline & right & left & & right & left & & right & left & \\
\hline $\begin{array}{l}\text { Low } \\
\left(<9^{\circ}\right) \\
n=74\end{array}$ & $4.8 \pm 1.6$ & $5.4 \pm 1.9$ & $0.002^{*}$ & $1.6 \pm 0.7$ & $1.6 \pm 0.9$ & 0.784 & $2.3 \pm 1.1$ & $2.7 \pm 1.6$ & $0.032^{*}$ \\
\hline $\begin{array}{l}\text { Medium } \\
\left(9^{\circ}-15^{\circ}\right) \\
\text { n=58 }\end{array}$ & $5.0 \pm 1.8$ & $5.7 \pm 2.2$ & $0.012^{*}$ & $1.7 \pm 0.6$ & $1.7 \pm 0.7$ & 0.43 & $2.7 \pm 1.1$ & $2.8 \pm 1.5$ & 0.33 \\
\hline $\begin{array}{l}\text { High } \\
\left(>15^{\circ}\right) \\
n=20\end{array}$ & $4.9 \pm 1.3$ & $6.0 \pm 2.5$ & $0.022^{*}$ & $1.6 \pm 0.8$ & $1.6 \pm 0.7$ & 0.795 & $2.4 \pm 1.1$ & $2.6 \pm 1.4$ & 0.616 \\
\hline
\end{tabular}


Table 3: Comparison of OMC spaces/distances according to left septum deviation degree (right-left)

\begin{tabular}{|c|c|c|c|c|c|c|c|c|c|}
\hline \multirow{2}{*}{$\begin{array}{l}\text { Left } \\
\text { septal } \\
\text { deviation } \\
\text { degree }\end{array}$} & \multicolumn{2}{|c|}{ LP-MNC } & \multirow[t]{2}{*}{$\mathbf{p}$} & \multicolumn{2}{|c|}{ UP-MNC } & \multirow[t]{2}{*}{$\mathbf{p}$} & \multicolumn{2}{|c|}{ LP-UP } & \multirow[t]{2}{*}{ p } \\
\hline & right & left & & right & left & & right & left & \\
\hline $\begin{array}{l}\text { Low } \\
\left(<9^{\circ}\right) \\
n=47\end{array}$ & $5.5 \pm 2.0$ & $5.0 \pm 1.7$ & 0.138 & $1.7 \pm 0.8$ & $1.7 \pm 0.5$ & 0.938 & $2.7 \pm 1.5$ & $2.5 \pm 1.2$ & 0.187 \\
\hline $\begin{array}{l}\text { Medium } \\
\left(9^{\circ}-15^{\circ}\right) \\
n=53\end{array}$ & $6.3 \pm 1.7$ & $5.5 \pm 2.0$ & $0.001^{*}$ & $2.1 \pm 0.9$ & $1.7 \pm 0.8$ & $0.001^{*}$ & $3.2 \pm 1.4$ & $2.6 \pm 1.1$ & $0.001^{*}$ \\
\hline $\begin{array}{l}\text { High } \\
\left(>15^{\circ}\right) \\
n=20\end{array}$ & $6.1 \pm 2.5$ & $5.1 \pm 1.4$ & $0.003^{*}$ & $1.9 \pm 0.6$ & $1.6 \pm 0.7$ & 0.13 & $2.7 \pm 1.4$ & $2.6 \pm 1.2$ & 0.82 \\
\hline
\end{tabular}

OMC: Osteomeatal complex, UP-MNC: Uncinate process-Middle nasal concha ,

LP-MNC: Lamina papyricea -Middle nasal concha LP-UP: Lamina papyricea -Uncinate process. Values are given in mm as mean $\pm \mathrm{SD}$.

\section{DISCUSSION}

Nasal septal deviation is defined as a shift of the nasal septum to the right or left. The cause of septal deviation may occur due to congenital and environmental factors ${ }^{9}$. Traumas of the facial region, especially during the developmental period, cause curvatures by disrupting the structure and development of the septum. Sometimes, septum curvatures can be seen in adults, although there is no history of trauma ${ }^{10-13}$.

The osteomeatal complex located on the lateral nasal wall of the nasal cavity is formed by the combination of several important anatomical structures. Since the osteomeatal complex serves as a junction for the nasal cavity and the paranasal sinuses, it is considered a critical area for the drainage of the paranasal sinuses ${ }^{14}$. In case of septal deviation, the nasal cavities take an asymmetrical shape. Septal deviation is associated with middle turbinate and lateral nasal wall abnormalities that cause osteomeatal obstruction causing sinusitis ${ }^{15}$.

Unal et al. in their study named the relationship between osteomeatal complex spaces/distances, bone and mucosal widths and the severity of chronic sinusitis, they observed the distance between LP-MNC to be significantly narrower in patients with maxillary and anterior ethmoidal sinus pathology compared to those without pathology. In addition, in cases with severemoderate frontal sinus pathology, the LP-MNC mucosal width was narrow compared to normal sinuses. They reported that there was a negative correlation between LP-MNC width and severity of maxillary sinusitis, UP-MNC mucosal width and severity of frontal, maxillary and anterior ethmoidal sinusitis, and between mucosal UPMNC width and severity of frontal sinusitis ${ }^{3}$. In our study, there is a narrowing in these distances in the presence of sinusitis not observed.

Mundra et al. ${ }^{15}$ in their study with 61 patients, they emphasized that the increase in the degree of deviation of the septum was associated with contralateral middle nasal concha abnormalities, bilateral sinus diseases and ethmoidal bulla. They reported that the increase in the degree of septal deviation was not directly related to osteomeatal complex obstructions and sinusitis. They stated that factors such as concha bullosa, giant ethmoidal bulla, which cause an increase in septal deviation, cause OMC obstructions and sinusitis.

Elahi et al. it was noted that patients with increased Nasal septal deviation had a higher incidence of OMC obstruction, although there was an increase in the incidence and severity of bilateral chronic sinus disease with increasing septal deviations ${ }^{16}$. Orlandi showed that there is a significant relationship between septal deviation and rhinosinusitis in patients with a septal deviation of at least $10^{\circ}{ }^{17}$. In contrast, Gregurics et al. in their study with 117 patients, they found that there was no correlation between sinusitis and the degree of septal deviation ${ }^{18}$.

In our study, low (right) and medium (left) grade septal deviation affected the infundibulum. Narrowing of the ethmoidal infundibulum is 
clinically important because it predisposes to sinusitis. Other parameters of the osteomeatal complex were found to be significant in left medium grade septal deviation, it was observed that the averages in the direction of deviation were low. In the literature, the measurements we used in this study were used in very few studies. Contrary to Orlandi's study, no significant difference was found between the distances of the OMC spaces and the presence of sinusitis. Narrowing in OMC distances was not found to be associated with the presence of sinusitis, similar to Gregurics et al.

\section{CONCLUSION}

There are many studies reporting that septal deviation is a predisposing factor to osteomeatal complex occlusions and sinusitis. In this study, it was observed that the increase in the septal deviation affects the distance between certain points in the osteomeatal complex and narrows this distance. No connection of osteomeatal complex constrictions with sinusitis was detected. Although many individuals with septal deviation were detected in the study, the number of individuals in the groups was lower according to the degree of septal deviation. In order to reveal the relationship between the degree of septal deviation and osteomeatal complex occlusions and sinusitis, larger studies with larger sample groups should be conducted.

\section{REFERENCES}

1. Cellina M, Gibelli D, Cappella A, Martinenghi C, Belloni E, Oliva G (2020). Nasal cavities and the nasal septum: Anatomical variants and assessment of features with computed tomography, The Neuroradiology Journal, Vol.33(4): 340-347.

2. Bandyopadhyay R, Biswas R, Bhattacherjee $S$, Pandit N, Ghosh S (2015). Osteomeatal Complex: A Study of Its Anatomical variation among Patients Attending North Bengal Medical Collegeand Hospital. Indian J Otolaryngol Head Neck Surg, 67(3): 281-286.

3. Ünal B, Arıkan OK, Bilgili Y, Koç C (2005). Relationship between the bony and mucosal widths of osteomeatal complex spaces/distances and the severity of chronic sinusitis - A CT study KBBForum,4(3): 111-114.

4. Rao J.J, Kumar E. C. V, Babu K. R, Chowdary V. S., Singh, J.S, Rangamani, V (2005). Classification of nasal septal deviations relation to sinonasal pathology, Indian Journal of Otolaryngology and Head and Neck Surgery, vol. 57 (3): 199-201.

5. Orhan I, Ormeci T, Aydin S, Altin G, Urger E,
Soylu E, Yilmaz F (2014). Morphometric analysis of the maxillary sinus in patients with nasal septum deviation. EurArch Otorhinolaryngol, 271(4): 727732.

6. Janovic N, Janovic A, Milicic B, Djuric M (2020). Relationship between nasal septum morphology and nasal obstruction symptom severity: computed tomography study. Braz J Otorhinolaryngol, 970: 1-8.

7. Kaya K.S, Türk B, Soytaş P.A, Vanlı E., Turgut, S (2019). Relationship between unilateral chronic otitis media and nasal septal and eustachian tube angles, KBB Uygulamalar1; 7(1): 38-42.

8. Yilmazsoy Y, Arslan A (2018). Assessment of the prevalence of Haller cell variation and the relation between Haller cell variation and maxillary sinusitis J Health Sci Med; 1(3): 54-58.

9. Hartman C, Holton N, Miller S, Yokley T, Marshall S, Srınıvasan S, Southard T (2016). Nasal Septal Deviation and Facial Skeletal Asymmetries. The Anatomical Record, 299: 295-306.

10. Jeppesen F, Windfeld I (1972). Dislocation of the Nasal Septal Cartilage in the Newborn. Acta Obstet Gynecol Scand, 51: 5-15.3.

11. Alpini D, Corti A, Brusa F, Bini A (1986). Septal Deviation in Newborn Infants. Int J Pediatr Otorhinolaryngol, 11:103-7.

12. Kent SE, Reid AP, Brain DJ (1988). Neonatal Septal Deviations. J R Soc Med, 81 (3): 132-135.

13. Sorri M, Laitakai K, Vainio- Mattila J, Hartikainen-Sorri AL (1990). Immediate Correction of Congenital Nazal Deformities; Follow-up of 8 Years. Int $\mathbf{J}$ Pediatr Otorhinolaryngol, 19(2): 77-83.

14. Arx T, Lozanoff S, Bornstein MM (2019). Extraoral anatomy in CBCT - a literature review Swiss Dental Journal, SSO 129:804-815.

15. Mundra RK, Gupta Y, Sinha R, Gupta A (2014). CT Scan Study of Influence of Septal Angle Deviation on LateralNasal Wall in Patients of Chronic Rhinosinusitis. Indian J Otolaryngol Head Neck Surg, Apr-Jun 66(2):187-190.

16. Elahi MM, Frenkiel S (2000). Septal deviation and chronic sinüs disease. Am J Rhinol, 14(3): 175-179.

17. Orlandi RR (2010). A systematic analysis of septal deviation associated with rhinosinusitis. Laryngoscope, 120:1687-1695.

18. Greguric T, Baudoin T, Tomljenovic D Grgic M Stefanovic M, Kalogjera L (2016). Relationship between nasal septal deformity, symptoms and 
disease severity in chronic rhinosinusitis. Eur Arch Otorhinolaryngol, 273:671-677. 